\title{
Penerapan Metode Exponential Smoothing Dalam Peramalan Biaya Pengolahan Peternakan Ayam
}

\author{
Novri Hadinata \\ Sistem Informasi, Universitas Bina Dharma \\ Jln.Jenderal Ahmad Yani No.02. Palembang \\ novri hadinata@binadarma.ac.id
}

\begin{abstract}
Abstrak-- Pembuatan sistem informasi untuk meramalkan biaya pengolahan peternakan ayam pada PT Musi Raya Prabumulih sehingga dapat memenuhi kebutuhan akan informasi yang diinginkan, sehingga pekerjaan menjadi lebih efektif dan efisien.Manfaat utama dari penelitian ini adalah memberikan hasil peramalan biaya pakan ternak ayam potong sehingga dapat membantu dalam mengambil keputusan untuk memudahkan melihat informasi mengenai biaya pengolahan pakan ternak pada PT Musi Raya Prabumulih. Sistem informasi peramalan kebutuhan bahan pakan ternak ayam potong menggunakan metode exponential smoothing diharapkan dapat membantu untuk membangun sistem informasi berbasis Web yang dituangkan dalam bentuk website ini dapat mempermudah pengusaha ternak ayam dalam membutuhi pakan ternak ayam dan metode exponential smoothing mempermudahkan informasi dalam peramalan untuk pakan ternak ayam bagi perusahaan peternakan
\end{abstract}

Kata Kunci-Exponenial Smoothing, PHP, Peramalan, Biaya

\section{Pendahuluan}

Salah satu aspek strategis perusahaan agar dapat bersaing dalam dunia bisnis adalah perencanaan dan tersedianya produk untukmemenuhi tuntutan pasar. Perencanaan produksi yang ditetapkan akan mempengaruhi tingkat produksi dan inventori guna mencapai tingkat efektifitas yang maksimal, hal ini perlu di dukung oleh faktor persediaan.

Metode Exponential Smoothing adalah sebuah metode yang mampu melakukan analisa terhadap sebuah factor atau beberapa faktor yang diketahui mempengaruhi terjadinya sebuah peristiwa dengan terdapat yang panjang antara kebutuhan akan pengetahuan terjadinya sebuah peristiwa di waktu mendatang dengan waktu telah terjadinya peristiwa tersebut dimasa lalu. Tujuan dari penelitian Penelitian ini adalah untuk membangun Sistem Informasi Peramalan Biaya Pengolahan Peternakan Ayam Menggunakan Metode Exponential Smoothing. Pada penelitian ini studi kasus pada PT. Raya Musi

\section{TINJAUAN PUSTAKA}

\section{A. Sistem Pendukung Keputusan}

Sistem Pendukung Keputusan (Decission Support System) adalah sistem informasi berbasis komputer yang menyediakan dukungan informasi yang interaktif bagi manajer dan praktisi bisnis selama proses pengambilan keputusan. Sistem Pendukung Keputusan menggunakan [1] model analitis, [2] database, [3] penilaian dan pandangan pembuat keputusan dan [4] proses pemodelan berbasis komputer yang interaktif untuk mendukung pembuatan keputusan bisnis yang semi terstruktur [12].

\section{B. Peramalan}

Semua metode peramalan menggunakan pengalamanpengalaman masa lalu untuk meramalkan masa depan yang mengandung ketidakpastian. Oleh karena itu metode peramalan mengasumsikan bahwa kondisi-kondisi yang menghasilkan data masa lalu tidak berbeda dengan kondisi masa datang kecuali variabel-variabel yang secara eksplisit digunakan dalam periode tersebut. Ramalan-ramalan bagi manajemen harus di anggap sebagai suatu system yang sistematik. Dengan kata lain, suatu ramalan janganlah di anggap sebagai suatu hal yang permanen atau statis. Sifat dinamis dari pasar mengharuskan suatu ramalan untuk dikaji ulang, direvisi, dan di diskusikan. Oleh karena itu tahap-tahap peramalan dapat dibagi menjadi sebagai berikut [2]:

1. Penentuan tujuan, pada tahap ini harus ditentukan alasan manager membutuhkan ramalan dan cara menggunakan hasil ramalan tersebut. Tujuan peramalan mempengaruhi panjangnya periode ramalan dan menentukan frekuensi revisi biasanya dilakukan secara tahunan, peramalan jangka menengah di revisi secara bulanan atau kuartalan, sedangkan peramalan jangka pendek di revisi secara harian ataupun mingguan.

2. Pemilihan teori yang relevan, pada tahap ini ditentukan hubungan teoritis yang menentukan perubahanperubahan variabel yang diramalkan. Suatu teori yang tepat guna akan selalu membantu seorang peramal dalam 
mengindentifikasi setiap kendala yang ada untuk dipecahkan dan dimasukkan ke dalam proses peramalan.

\section{Peternakan Ayam Pedaging}

Menurut [5], usaha peternakan ayam pedaging atau ayam broiler pada awalnya merupakan usaha sampingan dari usaha peternakan ayam petelur. Seiring dengan berjalannya waktu, industri peternakan ayam broiler saat ini telah banyak berdiri. melalui aktivitas bisnisnya yaitu memproduksi ayam pedaging, yang meliputi budidaya ayam broiler (farming operation) dan industri pengolahan daging ayam, industri peternakan ayam broiler telah memberikan peranan yang nyata terhadap perkembangan sub sektor peternakan di Indonesia. Usaha peternakan ayam broiler saat ini berkembang sangat pesat, baik dari segi skala usaha maupun dari segi tingkat efisiennya. Banyak para pelaku usaha menekuni usaha peternakan ayam broiler, baik secara sistem mandiri maupun secara sistem plasma. Alasannya adalah selain jumlah permintaan daging ayam yang terus meningkat, perputaran modal yang sangat cepat merupakan daya tarik tersendiri bagi para pelaku usaha untuk menekuni usaha peternakan ayam broiler ini.

Usaha peternakan dapat digolongkan menjadi beberapa bagian. Menurut Surat Keputusan Menteri Pertanian No.472/Kpts/TN.330/6/96, usaha peternakan terbagi menjadi tiga kategori, yaitu Peternak rakyat, Pengusaha Kecil Peternakan, dan Pengusaha Peternakan. Peternak Rakyat adalah peternak yang mengusahakan budidaya ayam dengan jumlah populasi maksimal 15.000 ekor per periode. Pengusaha kecil peternakan adalah peternak yang membudidayakan ayam dengan jumlah populasi maksimal 65.000 ekor per periode. Pengusaha peternakan adalah peternak yang membudidayakan ayam dengan jumlah populasi melebihi 65.000 ekor per periode [8].

\section{Pakan Ternak}

Menurut Rasyaf [8] Pakan atau ransum merupakan salah satu faktor utama dalam usaha ternak ayam broiler, lebih-lebih terhadap laju pertumbuhan dan peningkatan bobot badan yang sangat cepat. Ransum merupakan kumpulan bahan makanan yang layak dimakan oleh ayam dan telah disusun mengikuti aturan tertentu. Aturan itu meliputi nilai gizi bagi ayam dan nilai kandungan gizi dari bahan makanan yang digunakan. ransum starter diberikan pada ayam berumur satu sampai tiga minggu. Umumnya biaya untuk ransum menempati 60\%-75\% dari total biaya produksi. Ayam broiler membutuhkan energi yang lebih tinggi (lebih dari $3000 \mathrm{kkal}$ per kg ransum). dalam hal ransum yang harus diberikan untuk anak ayam sampai umur empat minggu, pakan harus mengandung protein sebanyak 21 sampai $24 \%$, lemak 2,5\%, serat kasar $4 \%$, kalsium $1 \%$, phospor 0,7 sampai $0,9 \%$, energi (ME) 2800$3500 \mathrm{kkal}$. Besarnya pakan yang digunakan mempengaruhi perhitungan konversi pakan atau Feed Corvertion Ratio (FCR). Konversi pakan merupakan perbandingan antara jumlah pakan yang dikonsumsi dengan pertumbuhan berat badan. Semakin tinggi konversi pakan berarti semakin boros pakan yang digunakan. Standar konversi pakan untuk ayam pedaging adalah 1,9 yang artinya untuk mendapatkan ayam denganbobot hidup $1 \mathrm{~kg}$ diperlukan pakan sejumlah $1,9 \mathrm{~kg}$. Feed Convertion Ratio (FCR) atau rasio konversi pakan merupakan satuan untuk menghitung efisiensi pakan pada budidaya pembesaran dan penggemukan. Dengan menghitung FCR dari ayam broiler. Hasil perhitungan FCR dengan angka yang kecil berarti pakan yang diberikan tersebut semakin bagus. Rumus menghitung FCR adalah jumlah pakan selama pemeliharaan dibagi total bobot ayam yang dipanen .

Contoh perhitungan :

Diketahui populasi ayam sebanyak 1000 ekor, menghasilkan berat ayam $1,3 \mathrm{~kg}$, dengan penggunaan pakan sebanyak 40 sak, maka FCR-nya adalah :

Diketahui, Populasi $=1000$ ekor Berat Ayam $=1,3$ Banyaknya Pakan $=40$ sak $(1 \mathrm{sak}=50 \mathrm{~kg})=2000 \mathrm{~kg}$ Ditanyakan, Berapa FCR-nya?

Penyelesaian :

Berat total ayam yang dipanen $=1000 \times 1,3=1300 \mathrm{~kg}$ Feed Convertion Ratio $($ FCR $)=2000 / 1300=1,54$

\section{Metode Exponential SMOOTHING}

Metode exponential smoothing adalah suatu prosedur yang mengulang perhitungan secara terus menerus yang menggunakan data terbaru. Setiap data diberi bobot, dimana bobot yang digunakan disimbolkan dengan $\alpha$. Simbol $\alpha$ bisa ditentukan secara bebas, yang mengurangi forecast error. Nilai konstanta pemulusan, $\alpha$, dapat dipilih diantara nilai 0 dan, karena berlaku: $0<\alpha<1$ (5). Secara metematis, persamaan penulisan eksponential sebagai berikut (10): $\mathrm{St}+1=\alpha \mathrm{Xt}+(1$ $-\alpha) \mathrm{St}$

\section{Dimana :}

$$
\begin{aligned}
& \mathrm{St}+1=\text { Nilai ramalan untuk periode berikutnya } \\
& \text { a }=\text { Konstanta penulisan (0-1) }
\end{aligned}
$$

Nilai $\alpha$ yang menghasilkan tingkat kesalahannya yang paling kecil adalah yang dipilih dalam peramalan [3]. Metode ini lebih cocok digunakan untuk meramal hal-hal yang fluktuasinya secara random atau tidak teratur [10].

\section{HASIL DAN PEMBAHASAN}

Setelah melakukan kegiatan analisis, desain dan rekayasa sistem yang telah dibahas sebelumnya, maka hasil yang diperoleh adalah sebuah sistem informasi peramalan kebutuhan bahan pakan ternak ayam potong menggunakan 
metode Exponential Smoothing (study kasus pt. musi raya prabumulih).

Pada halaman peramalan pekan hanya dapat melihat hasil peramalan pekan yang diinputkan oleh admin. Adapun jelasnya lihat gambar dibawah ini

Pada pembahasan program yang sudah dilakukan testing dapat hasil bahwa sudah berkerja dengan baik tanpa mengalami kesalahan. Program ini mampu menghitung peramalan dengan benar dapat mengatasi peramalan persedian ternak.

Padapengujian program hasil yang diperolehdari proses peramalan menggunakan metode Exponential Smoothing. Dalam penyelesai peramalan pada perperiode PT Musi Raya Prabumulih meliki 7 periode dalam persedian keluar yang terdapat ayam potong dengan berusia 1-3 hari dan poor H10.

Dimamaada10 data asliAyamPotong yang berumur 1-3 haridanpakan Poor H10 yang melakukanperamalanmenggunakan data persediankeluar, untukmelakukantahappenyelesaianperamalandenganmetodeEx pnonentialSmootingmenggunakanrumus

$\mathrm{St}+1=\mathrm{aXt}+(1-\mathrm{a}) \mathrm{St}$

Maka Hasil peramalan menggunakan penyelesai menggunkan rumus Exponential Smooting

Tabel 1. Hasil Peramalan

\begin{tabular}{|c|c|c|c|c|c|}
\hline \multicolumn{6}{|c|}{ Exponential Smoothing Dengan Nilai $\operatorname{Alpha}(\alpha)=0.1$} \\
\hline \multicolumn{3}{|c|}{$\begin{array}{c}\text { Data Kebutuhan Pakan } \\
\text { Sebelumnya }\end{array}$} & \multicolumn{3}{|c|}{ Hasil Peramalan } \\
\hline & Periode & $\begin{array}{l}\text { Kebutuhan } \\
\text { Pakan } \\
\text { Per } \\
\text { Karung(Xt) }\end{array}$ & $\begin{array}{l}\text { Peramalan } \\
\quad(\mathrm{Ft})\end{array}$ & $\begin{array}{c}\mathrm{Xt}- \\
\mathrm{Ft}\end{array}$ & $\mathrm{Xt}-\mathrm{Ft}^{\wedge} 2$ \\
\hline 1 & Periode 1 & 3 & - & - & - \\
\hline 2 & Periode 2 & 3 & 3 & 0 & 0 \\
\hline 3 & Periode 3 & 3 & 3 & 0 & 0 \\
\hline 4 & Periode 4 & 3 & 3 & 0 & 0 \\
\hline 5 & Periode 5 & 3 & 3 & 0 & 0 \\
\hline 6 & Periode 6 & 4 & 3 & 1 & 1 \\
\hline 7 & Periode 7 & 13 & 3.1 & -0.1 & 0.01 \\
\hline 8 & Periode 8 & 3 & 3.09 & -0.9 & 0.0081 \\
\hline 9 & Periode 9 & 3 & 3.081 & -0.081 & 0.0066 \\
\hline 10 & Periode 10 & 3 & 3.0729 & 0.0729 & 0.0053 \\
\hline & $\begin{array}{c}\text { Periode } \\
\text { Selanjutnya }\end{array}$ & - & 3.0656 & - & - \\
\hline & & & 3.059 & & \\
\hline
\end{tabular}

\begin{tabular}{|c|c|c|c|c|}
\hline \multicolumn{5}{|c|}{ Exponential Smoothing Dengan Nilai Alpha $(\alpha)=0.1$} \\
\hline \multicolumn{2}{|c|}{$\begin{array}{c}\text { Data Kebutuhan Pakan } \\
\text { Sebelumnya }\end{array}$} & \multicolumn{3}{|c|}{ Hasil Peramalan } \\
\hline Periode & $\begin{array}{c}\text { Kebutuhan } \\
\text { Pakan } \\
\text { Per } \\
\text { Karung(Xt) }\end{array}$ & $\begin{array}{c}\text { Peramalan } \\
(\mathrm{Ft})\end{array}$ & $\begin{array}{c}\mathrm{Xt}- \\
\mathrm{Ft}\end{array}$ & $\mathrm{Xt}-\mathrm{Ft}^{\wedge} 2$ \\
\hline & & 3.0531 & & \\
\hline & & 3.0478 & & 1.03 \\
\hline & Total Xt - Ft^2 & 0.0858 \\
\hline \multicolumn{4}{|c|}{ Nilai MSE } \\
\hline \multicolumn{3}{|c|}{ Total Biaya : } \\
\hline
\end{tabular}

Untuk cara penyelesain peramalan data diatas sebagai berikut :

Periode ke $-1=$

$\mathrm{St}=3 \quad \mathrm{x} \quad 0.1+3.0729 \quad \mathrm{x} \quad(1-0.1)=0.3+3.0729 \quad \mathrm{x}$ $0.9=0.3+2.76561=3.06561$

Periode ke $-2=$

$$
\mathrm{St}=3 \quad \mathrm{x} \quad 0.1+3.06561 \quad \mathrm{x} \quad(1-0.1)=0.3+3.06561 \quad \mathrm{x}
$$
$0.9=0.3+2.75905=3.05905$

Periode ke $-3=$

$$
\mathrm{St}=3 \quad \mathrm{x} \quad 0.1+3.05905 \mathrm{x} \quad(1-0.1)=0.3+3.05905 \mathrm{x}
$$
$0.9=0.3+2.75314=3.05314$

Periode $\mathrm{k} 3-4=$

$\mathrm{St}=3 \quad \mathrm{x} \quad 0.1+3.05314 \quad \mathrm{x} \quad(1-0.1)=0.3+3.05314 \quad \mathrm{x}$ $0.9=0.3+2.74783=3.04783$

Perhitungan di atas dilakukan dalam 4 periode makan untuk hasil dari peramalan akan menghasilkan Total $\mathrm{Xt}-\mathrm{Ft}^{\wedge} 21.03$ dan Nilai MSE 0.0858 dari hasil diatas mendapatkan Total biaya yang berjumlah Rp. 1.103.616

Pada tahapan ini proses yang akan dilakukan adalah implementasi dan pengujian pada sistem infomasi monitoring penerimaan dan pelaksanaan proyek sudah dirancang, dengan tujuan untuk menerapkan rancangan sistem informasi kepada sistem yang telah berjalan sehingga user dapat meninjau dan memberikan masukan untuk perkembangan sistem yang telah dibuat.

\section{KESIMPULAN}

\section{A. Kesimpulan}

Berdasarkan uraian yang telah disampikan pada bab-bab sebelumnya, maka dapat ditarik kesimpulan sebagai berikut : 
- Sistem informasi peramalan kebutuhan bahan pakan ternak ayam potong menggunakan metode exponential smoothing (study kasus pt. musi raya prabumulih) diharapkan system informasi berbasis Web yang dituangkan dalam bentuk website ini dapat mempermudah pengusaha ternak ayam dalam membutuih pakan ternak ayam.

- Sistemin iformasi peramalan kebutuhan bahan pakan ternak ayam potong menggunakan metode exponential smoothing (study kasus pt. musi raya prabumulih) mempermudahkan informasi dalam peralaman untuk pakan ternak ayam bagi pengusan peternakan.

\section{B. Saran}

- Harus adanya pemeliharaan terhadap sistem yang telah dibuat agar sistem dapat terjaga dengan baik.

- Untuk mempermudah menjalankan aplikasi, perlu adanya pelatihan bagi karyawan tentang aplikasi yang dibuat.

- Perlu dilakukan pengembangan lebih lanjut tentang aplikasi ini.

\section{DAFTAR PUSTAKA}

[1] Abdul Kadir. 2002. "Pengenalan Sistem Informasi". Andi. Yogyakarta.

[2] Arsyad, L. (2001). "Peramalan Bisnis", BPFE Yogyakarta, Yogyakarta.

[3] Arsyat, Lincolin 1997. "Peramalan Bisnis", BPFE, Yogyakarta.

[4] Fiati, R., 2009, Sistem Pendukung Keputusan Peramalan Penjualan Barang, Tesis, Magister Ilmu Komputer Program Pascasarjana Universitas Gadjah Mada Yogyakarta.

[5] Hafsah. 2003. "Pengaruh suplementasi probiotik starbio terhadap rasio effisiensi protein ransum dan nilai karkas ayam pedaging". Jurnal Agroland 10 (4): 399-404.

[6] Jogiyanto, Hartono. 2005. "Analisis dan Desain Sistem Informasi". Yogyakarta Grafindo Persada.

[7] Rasyaf, M., 2003. "Beternak Ayam Pedaging". Penebar Swadaya, Jakarta. Utama, Jakarta.

[8] Rasyaf, M. 1989. "Memelihara Ayam Buras". Kanisius, Yogyakarta.

[9] Sprague, R.H., dan Watson. H.J. 1993. "Decision Support System, Putting Theory into Practice". Edisi 3. Prentice Hall Inc.

[10] Subagyo, et al. 2002. "Bank dan Lembaga Keuangan Lainnya". Yogyakarta: Bagian Penerbitan Sekolah Tinggi Ilmu Ekonomi YKPN.

[11] Supardi. 2005. "Metodologi Penelitian Ekonomi \& Bisnis". Yogyakarta : UII Press.

[12] Turban, E., 2001, Decision Support Systems and Expert Systems and Intelligent Systems, 6th Edition, Prentice Hall Internasional, Inc., New Jersey. 